\title{
Timber Market Information on Leyte Island, the Philippines
}

\author{
Edwin Cedamon, Steve Harrison and John Herbohn
}

\author{
School of Natural and Rural Systems Management \\ The University of Queensland, Gatton, Queensland 4343, Australia
}

\begin{abstract}
Information is essential in making marketing decisions. This paper presents an assessment of information concerning the timber market in Leyte Island, focusing on sources, how to access supply and demand information, and usefulness and limitations of available information. The sources of timber market information include (i) Philippine Forestry Statistics, (ii) a database of registered tree plantations, (iii) a barangay-based inventory of trees on farms, and (iv) tree measurements and data collected in the timber enterprise survey conducted by the ACIAR Tree Farm Project. Based on available secondary data, there are 27,635 ha of forest in Leyte that is potentially harvestable. In addition, based on the findings of the barangay-based tree farm inventory, there are approximately $2.7 \mathrm{M}$ trees on tree farms on Leyte Island. Timber demand by entrepreneurs on Leyte Island has not been calculated yet from the available survey data of the ACIAR Tree Farmer Project; however, estimates show that the annual per capita timber consumption of the Philippines for 2005 was 7.8 board feet. It was found that although some secondary data on timber market information are available from government agencies, particularly the Department of Environment and Natural Resources, consumer and producer-level data are scarce. Most of the producer and consumer-level data available to date were gathered through the ACIAR Tree Farm Project.
\end{abstract}

Keywords: registered tree plantations, trees-on-farms inventory, timber enterprise survey, per capita timber consumption

\section{INTRODUCTION}

Modelling the timber market in Leyte has been identified as a key activity of the Australian Centre for International Agricultural Research (ACIAR) Tree Farmer Project (ASEM 2003/052) on Leyte Island. This research activity basically aims to understand how smallholder tree farmers on Leyte Island could gain access to markets for their timber products with maximum returns. This investigation is being undertaken as part of a higher degree study of the timber market using linear programming (LP) as the overarching methodology. Fundamental to this research is the access to and analysis of timber supply and demand information for Leyte Island. 
Information is essential for market actors in making transaction decisions (Wang and Van Kooten 2001), and consequently markets lose efficiency due to lack of information. It has been argued by Emtage (2004) that tree farmers lack knowledge on where and how to market their timber products, while timber buyers have difficulty obtaining local timber (DENR 2006). This situation on Leyte Island clearly illustrates a problem of lack of market information for timber products. Wang and Van Kooten (2001) identified two aspects of information - information deficiency and information asymmetry. Information deficiency arises from incomplete information and the difficulty of making information available. Information asymmetry arises in situations where one party to an exchange has information that is not available at any cost to the other party (McTaggart et al. 2003).

This paper discusses timber market information available from the Department of Environment and Natural Resources (DENR) and the ACIAR Tree Farm Project (hereafter referred to as the ACIAR Project) based at Visayas State University on Leyte Island, the Philippines, and how to access it. Timber market information for Leyte Island is analysed with a view to estimating timber supply and demand, for a number of districts. The next section presents available information concerning timber supply sources and quantities. Estimates of forest cover for Leyte Island are presented and the limitations of the database of registered tree plantations are discussed. An estimate of the number of trees on smallholder tree farms derived through a barangaybased inventory study is then presented. The timber enterprise survey of the ACIAR project as a source of timber demand information is described, and per capita annual timber consumption estimated. Finally, the usefulness and limitation of available information in estimating timber supply and demand are assessed.

\section{INFORMATION ON TIMBER SUPPLY}

Some sources of timber supply information for Leyte Island as well as ways to access them are summarized in Table 1. The Philippine Forestry Statistics are available on the Department of Environment and Natural Resources (DENR) website from year 1990 to 2005. This yearbook includes various types of information related to forestry and forest industry, including estimates of the plantation area established under various tenurial arrangements, by region and province. The data are mostly on spreadsheets and are downloadable.

The Community Environment and Natural Resources Offices (CENROs) ${ }^{1}$ have lists of registered tree plantations, including details on owners, species planted, area planted, number of trees and year planted. Information related to yield of three plantation species - Gmelina arborea (gmelina), Swietenia macrophylla (mahogany) and Acacia mangium (mangium) - is available from the ACIAR project based at College of Forestry and Natural Resources, Visayas State University, Baybay City, Leyte. Information on the barangay-based inventory of tree farms covering a number of barangays in seven randomly selected Leyte Island municipalities is also available from the ACIAR Project. Available information has been assessed in view of estimating timber supply and is presented in the following sections.

${ }^{1}$ CENROs cover a number of municipalities. There is at least one CENRO in a province. 
Table 1. Sources of timber supply information and ways to access them

Source of information

Philippine Forestry

Statistics, available from DENR

\section{Type of information} Forest cover estimates; area of plantations established under various tenurial arrangements
List of registered tree plantations, available from CENROs

Tree farm inventory information in sample municipalities in Leyte Island, available at ACIAR Tree Farm Project
Details of owners of registered tree plantation, details of trees planted, e.g. species, year planted, area of plantation, and estimates of merchantable volume Farm profile, e.g. location, planting pattern, year of planting, and GIS data for mapping; biophysical profile, e.g. soil characteristics, slope, elevation; basic timber inventory data, e.g. diameter at breast height (dbh), diameters and lengths of log sections, bark thickness, and crown cover

Barangay-based inventory of tree farms in sample municipalities in Leyte Island, available from the ACIAR Tree Farm Project
Estimates of number of trees per farm and year planted, species, tenure and location
Reports can be access through the Project Leaders, ACIAR Tree Farm Project, CFNR, Visayas State University, Baybay City, Leyte, the Philippines

\section{Estimates of Forest Cover on Leyte Island}

Forest inventory reports could be a major source of information on timber supply in a particular country or region. A forest inventory is a description of quantity and quality of trees (and sometimes of other organisms found in the forest) (Shiver and Borders 1996). The DENR conducted a National Forest Assessment (NFA) for the year 20022003 which produced estimates of forest cover throughout the Philippines (DENR 2007). A report of the methodology and results of the forest assessment can be found in Acosta (2005), FAO (2005) and the 2005 Philippines Forestry Statistics (DENR 2007). 
The 2005 Philippine Forestry Statistics ${ }^{2}$ indicate that there are at least 95,019 ha of forest on Leyte Island (Table 2). About 90\% of the forest area is located in forestland and $10 \%$ in A\&D land ${ }^{3}$. Closed ${ }^{4}$, open ${ }^{5}$ and mangrove forests in forestland are basically natural forest in which harvesting is banned. Therefore, the forest area that could be expected to supply wood for the timber industry is 13,648 ha. It is indicated in the 2005 Forestry Statistics that data for plantation forests are incomplete and as a consequence no estimates have been made on the total area of plantation forest on Leyte Province in the areas reported in Table 2. A forest plantation has been defined as a forest stand established by planting or seeding in the process of afforestation or reforestation (DENR 2005; FAO 2005).

Table 2. Forest cover on Leyte Island

\begin{tabular}{lcc}
\hline Forest type & \multicolumn{2}{c}{ Land area (ha) } \\
\cline { 2 - 3 } & Forestland area (ha) & A\&D land area (ha) \\
\hline Closed forest & 4269 & - \\
Open forest & 74,910 & 4253 \\
Mangrove forest & 2192 & 2665 \\
Plantation forest $^{\text {a }}$ & 4613 & 2117 \\
\hline Total forest area & 85,984 & 9035 \\
\hline
\end{tabular}

Source: DENR (2007).

a. Data for Southern Leyte Province. No data available for Leyte Province.

While no estimate of forest plantations in forestland in Leyte Province is available in the report on forest cover of the 2005 Forestry Statistics, data on areas of forest plantations established in forestland under various tenurial instruments are available in another report of the 2005 Forestry Statistics. These tenurial instruments include the Socialized Industrial Forest Management Agreement (SIFMA), Industrial Forest Management Agreement (IFMA), Industrial Tree Plantation Lease Agreement (ITPLA), Tree Farm and Agroforestry Lease Agreement (TFALA), and Private Forest Development Agreement (PFDA). Most of these tenurial instruments are explained by Harrison et al. (2004). In addition, the record of Community Based Forest Management (CBFM) plantations in Region 8 was obtained from the DENR regional office in Region

${ }^{2}$ The 2005 Philippine Forestry Statistics can be obtained through the DENR website, at www.denr.gov.ph, or by requesting a printed copy from the Forest Management Bureau, DENR, Visayas Avenue, Diliman Quezon City, the Philippines.

${ }^{3}$ In essence, alienable and disposable (A\&D) land is freehold land, while forestland is government-owned land, which approximates leasehold land. Forestland is typically steep land, much of which is available for farming if an annual tax is paid, and is called 'tax declaration land'.

${ }^{4}$ Closed forests are formations where trees in the various storeys and the undergrowth cover a high proportion ( $>40 \%$ ) of the ground and which do not have a continuous dense grass layer (FAO 2006).

5 These are open-forest formations where trees form a discontinuous layer covering between $10 \%$ and $40 \%$ of ground area (FAO 2006). 
8 and this includes data for Leyte Province. Data from these sources are presented in Table 3.

Table 3. Estimated area of forest plantation in Leyte Province under tenurial instruments

\begin{tabular}{lc}
\hline Tenurial instrument & Forest area (ha) \\
\hline CBFMA $^{2}$ & 25,100 \\
IFMA/ITP $^{1}$ & 572 \\
TFALA $^{1}$ & 3300 \\
SIFMA $^{1}$ & 20 \\
PFDA $^{1}$ & 55 \\
\hline Total forest area (ha) & 29,047 \\
\hline Estimated productive forest (ha) & 13,987 \\
\hline
\end{tabular}

${ }^{1}$ No data for Southern Leyte Province; data obtained from DENR (2007).

${ }^{2}$ Data obtained from records of the DENR provincial office in Region 8.

As shown in Table 3, there is a relatively large area of forest plantation under Community Based Forest Management Agreement (CBFMA). Based on interviews with staff of the Forest Management Service of DENR Region 8, this estimate is not reliable because it is based mainly on reported area planted during the establishment phase and in some areas mortality has been high and some areas in plantations exist only on paper. Germano (2007) made a conservative estimate that only about $40 \%$ of the reported area of forest plantation can be considered productive forest because, aside from the high mortality rate, some areas in CBFMAs are protected and hence harvesting is not allowed. This is consistent with the area reported for plantation forest in forestland for Southern Leyte Province in Table 2, which is only $43 \%$ of the area of forest plantation that appeared on the record of CBFMAs obtained from DENR Region 8. Therefore, it can be estimated that only about 10,040 ha of the CBFM plantation in Leyte Province is productive forest. Moreover, the total harvestable forest area in both forestland and A\&D land is 27,635 ha. This estimate is the total area of forest plantations on $A \& D$ land and forestland including those forest plantations in forestland under tenurial instruments.

\section{The DENR Database of Registered Tree Plantations}

Current government regulations on trees planted on A\&D land encourage plantation owners to register their trees with the CENRO to avoid hassles in selling timber. As a result, each CENRO has a compilation of the list of tree registrants, usually in an Excel spreadsheet which is available for public access. However, Cedamon et al. (2005) argued that the lists of registered tree plantations at the CENROs are not reliable because:

- either the tree farms or the tree farm owners listed in the database do not exist;

- some of tree farms have low stocking compared to what was reported; and

- few farmers register their plantations. 
It is recognized, however, that poor data are better than no data at all. Therefore, for estimating timber supply, the number of trees planted in registered tree plantations could provide some insights into the trend of tree planting on private land.

\section{The 'Whiteboard' Timber Information System Trial}

The tree registration data of CENRO Maasin in Leyte Island was used in the recent trial of the ACIAR Tree Farm Project to link buyers and sellers of timber, in collaboration with CENRO Maasin. Two 'whiteboards' have been set up outside the CENRO office to provide timber demand and supply information to various stakeholders, particularly tree farmers and timber buyers and dealers. Each board measures 4 feet by 8 feet $(1.2 \mathrm{~m}$ x $2.4 \mathrm{~m})$. One of the boards shows a list of about 160 registered tree plantations. Information includes the name of plantation owner, location of plantation, species planted, and estimates of merchantable volume for some plantations. The boards are displayed at the entrance of the CENRO office so that they can easily be seen by clients. This information is valuable for timber buyers, i.e. for lumber merchants and wood processors looking for potential timber sources. This is the main purpose of the trial, to link sellers and buyers of timber. This trial has been conducted only in CENRO Maasin but there are plans to install whiteboard information systems in other CENRO districts if found useful based in the recent evaluation study conducted. The information contained on the other whiteboard relates to demand of timber buyers and is discussed in timber demand section below.

\section{Barangay-based Estimates on Number of Trees on Farms}

It has been reported by a number of authors - e.g. Emtage (2004), Cedamon et al. (2005) and Herbohn (2005) - that there are many farmers on Leyte Island who have planted trees on their farms. Most of these trees are planted in small patches, often incorporated with other crops such as coconuts and bananas. The tree planting is sometimes described as smallholder 'tree farming' because of the scale of timber growing and the planting pattern of the relatively resource-poor farmers.

The ACIAR Tree Farm Project operating on Leyte Island requested barangay chairmen in the seven sample municipalities to submit data of households and individuals who have planted trees in their respective barangays. A series of consultations and meetings were conducted in municipalities on how these data could be obtained successfully. Detailed methodology and research highlights have been reported by Cedamon (2007) and Cedamon et al. (2007). The barangay-based inventory of TOF in selected municipalities on Leyte Island is valuable information to estimate timber supply from smallholder tree farms. It should be noted that the barangay-based inventory study is a pioneering attempt initiated by the ACIAR Tree Farm Project to estimate tree resources outside forests on Leyte Island.

Out of 178 barangays selected for the tree measurement study, 108 barangays were selected for the inventory of trees on farms. This excluded barangays which have no list of tree farms, i.e. those located in urban areas and in coastal areas where little tree planting takes place. It can be considered, therefore, that the number of barangays is a statistically sufficient sample to estimate the number of trees on the island. Based on the tree farm inventory, it was estimated that on average, each farming household on Leyte Island was growing 136 trees on their farm and an average of 10 households in 
every barangay had planted trees. Leyte Island consists of 1990 barangays. Therefore, it could be estimated that Leyte Island has 19,900 smallholders growing $2.7 \mathrm{M}$ trees which could be equal to about 1600 ha of forest plantation, following the $3 \mathrm{~m} \mathrm{x} 3 \mathrm{~m}$ planting pattern.

The reliability of the barangay-based inventory of tree farms was evaluated by locating tree farms, identifying tree species and counting the number of trees found in 10 sample barangays of the seven sample municipalities. Farmers were also interviewed to determine the year of planting. It was found that the barangay-based tree farm inventory had an accuracy of $\pm 30 \%$ in estimating count and age of trees on tree farms.

\section{Volume Estimates from Tree Measurements Conducted by ACIAR Tree Farm Project}

The ACIAR Tree Farm Project had conducted measurements of trees on smallholder farms on A\&D land on Leyte Island. One of the outputs of this research to date is the development of a site index equation for gmelina (Gmelina arborea Roxb.) by Vanclay et al. (2005). Work is in progress to derive site index equations for mahogany (Swietenia macrophylla) and mangium (Acacia mangium Willd.). It has been pointed out by Vanclay et al. (2005) that the mean annual increment is highly correlated with the site index, hence the site index can be used to predict volume of standing trees. With the availability of volume equations and volume tables, timber quantity can be estimated based on forest inventory information available from government agencies, particularly the DENR.

\section{ESTIMATING THE QUANTITY OF TIMBER DEMANDED BASED ON THE SURVEY OF TIMBER ENTREPRENEURS}

Timber demand for a given time period refers to 'stumpage quantities that some group would purchase for harvesting at different stumpage prices' (Klemperer 2003). In studying timber demand, it should be considered first and foremost that demand for timber is a 'derived' demand (Pearse 1990, p. 48), which is the demand for an intermediate good that is derived from consumer demand for final product (Klemperer 2003). Thus, the demand for sawntimber is derived from the demand for timber products. Therefore, in assessing market information concerning timber demand, it is necessary to consider the various industries using wood as their raw material. Observations by the authors reveal that demand for wood on Leyte Island is mainly for house construction and repairs and maintenance, fuelwood, furniture, industrial wood (e.g. pallets and dunnage ${ }^{6}$ as well as small quantities for boat making). There is no pulp and paper mill on the island using wood as raw material. Industrial wood such as pallets are used in many seaports and enterprises, including the Philippine Phosphate Corporation (Philphos), Philippine Associated Smelting and Refinery Corporation (PASAR), and bottling companies (including Coca-cola, Pepsi and San Miguel Beer).

\footnotetext{
${ }^{6}$ Dunnage is wood used to support, load or prop cargo off the ground or floor. In Leyte, the PASAR Company requires dunnage in the manufacture of copper cathodes.
} 
Dunnage is particularly demanded by PASAR and a considerable volume of fuelwood is required by Philphos and PASAR in their operations.

Literature search failed to locate any estimates of timber demand by various markets on Leyte Island. The most recent demand-side information available on the timber industry is the survey of timber entrepreneurs in Leyte, Samar, Biliran and Cebu conducted by the ACIAR Tree Farm Project. Respondents of the survey included lumber retailers and lumber processors ${ }^{7}$. Information gathered from the survey includes the following:

- overview of their business activities,

- timber procurement volume and buying price by species, dimensions and sources,

- volume and selling prices of timber products sold by location, species and product type,

- managers' views on smallholder tree farms as a sources of timber resource, and

- managers' perceptions of future prospects for their enterprise and the overall Philippines timber industry.

Eight types of timber buyers were identified by respondents, as listed in Table 4 . Building contractors are those firms or individuals who have contracts to construct commercial and residential buildings. This type of buyer generally requires a high volume of timber for construction. Local consumers are basically local households who need timber for small-scale repairs and minor house construction and furniture use. These two groups of consumers are generally the largest market for timber in Leyte Island.

Table 4. Numbers of timber buyers in Leyte, Samar, Biliran and Cebu

\begin{tabular}{lc}
\hline Regular buyer type & Number of entrepreneurs \\
\hline Building contractor & 16 \\
Local consumers & 41 \\
Furniture maker (export) & 9 \\
Furniture maker (local) & 8 \\
Hardware/lumber retailer & 5 \\
Government institution & 5 \\
Veneer plant & 1 \\
Non-government institution & 1 \\
\hline
\end{tabular}

Source: Cedamon, J. et al. (2007).

The timber volume purchased by the enterprises included in the survey was investigated, and could be used to estimate demand at consumer level which could then be used, along with other market factors including prices, income and inflation, to

\footnotetext{
${ }^{7}$ Furniture makers who purchase lumber were included in the survey.
} 
predict demand in a given time period in the future. At the time of writing, the data obtained from this survey are still being analysed.

The ACIAR Tree Farm Project information board trial at CENRO Maasin provides additional information on market demand for timber. Information contained on the board includes name and contact details of timber buyers, dimensions of timber they buy and prices they offer for each sawn timber dimension. This is the key information which tree farm owners and other timber producers and sellers need in gaining market access. Furthermore, tree growers often visit CENROs to obtain cutting and transport permits at which time - if they see the information board - would be helped in planning for timber selling and in obtaining a fair price for their timber.

\section{ESTIMATING TIMBER CONSUMPTION BASED ON IMPORT, EXPORT AND LUMBER PRODUCTION DATA}

The estimated volume of timber demanded by the enterprises from the survey conducted by the ACIAR Tree Farm Project was not available at the time of writing this paper. In the absence of estimates of household timber consumption from the enterprise survey, apparent consumption of wood in a given region could be estimated by adding the volume of imports to local production then subtracting exports (Gregory 1987, p. 43). The per capita consumption can be calculated using the national or regional statistics collected in the national census of population and housing. The volume data ${ }^{8}$ (Table 5) on solid wood (log and lumber) production, imports and exports for the Philippines was obtained from 2005 Philippine Forestry Statistics (DENR 2007), while population data were obtained from the website of the Philippine National Statistics Office (www.census.gov.ph). The total Philippines population for 2005 was estimated as $85,386,300^{9}$. It could therefore be inferred that the apparent per capita consumption of solid wood for the year 2005 in the Philippines is $0.018 \mathrm{~m}^{3}$ or $7.58 \mathrm{bdft}$.

Table 5. Data used in estimating apparent per capita consumption of solid wood in the Philippines for 2005

\begin{tabular}{lr}
\hline Timber production and consumption item & Volume $\left(\mathrm{m}^{3}\right)$ \\
\hline Log production & 840,980 \\
Lumber production & 287,855 \\
Log import & 164,959 \\
Lumber import & 362,509 \\
Log export & 46 \\
Lumber export & 13,0175 \\
National timber consumption & $1,526,082$ \\
Estimated per capita consumption & 0.018 \\
\hline
\end{tabular}

${ }^{8}$ Data on lumber and log production by province are available from Forestry Statistics but data on imports and exports by province are lacking

${ }^{9}$ This is a projected population based on the May 2000 Census of Population and Housing; no further census has been conducted since then. 


\section{DISCUSSION AND CONCLUSION}

There is a clear scarcity of data on timber supply and demand on Leyte Island, the Philippines. The Philippine Forestry Statistics provide limited information on forest cover by region but no details on species, age distribution and standing volume. Detailed information such as owners, species, planting years and location of plantations could be obtained from DENR regional offices, or from other sources they can identify. Access to this information would require a close cooperation with DENR which is the sole government agency that has authority over forest resources. Accuracy of estimates is vital if reliable estimates of timber supply and demand are to be generated. It is suggested that data from DENR would require ground validation to determine their accuracy.

The barangay-based tree farm inventory has been shown to be an effective and efficient way to gather information on trees growing outside the technically defined 'forest' area. This type of inventory would require some effort in developing a relationship with Local Government Units (LGUs) who are the gatekeepers in municipalities and explaining to barangay chairmen the type of information needed. The financial requirement for going through this process is believed to be smaller than for employing enumerators to conduct an inventory. It should be noted that only number of trees, age and identification of species could be obtained from this inventory technique, and estimating timber turnoff volumes would be a separate step.

Measurements of trees on farms conducted by the ACIAR Tree Farm Project could provide estimates of yield by species for Leyte Island. This is useful to estimate aggregate timber supply volume in a given time period. However, assumptions should be specified in using the developed yield equations considering that management regimes vary between forest owners.

The timber enterprise survey conducted by the ACIAR project could provide a tremendous amount of information on quantity, quality, prices and product specifications demanded by the market. The quantity and quality of timber demanded by consumers particularly on Leyte Island could be estimated based on the demand by timber enterprises. A survey of timber enterprises is an appropriate approach to collect consumer level data. In the absence of consumer level data, apparent consumption can be estimated based on secondary information on timber production, exports and imports.

In summary, timber market information for Leyte Island is scarce and therefore making this information available to market actors to support decisions on timber growing and marketing remains a challenge. There could be a 'vice versa' effect of the lack of formal timber market and lack of market information. The timber market modelling currently being undertaken is designed to provide substantial timber information that will be available for timber industry players - tree growers, timber processors, and timber products dealers. 


\section{REFERENCES}

ACOSTA, R. 2005. State of the Philippine forests: The National Forest Assessment of 2003. Paper presented to The Philippines Forestry Development Forum, Sustainable Forest Management: A Holistic Path to National Development, Mandaluyong City. 2-3 June 2005.

CEDAMON, E. 2007. 'Reliability of Barangay-based inventory of smallholder tree farms on Leyte Island. Leyte State University, the Philippines.

CEDAMON, E., BERNALDEZ, S. and J. BAYNES. 2005. Trials and tribulations in locating tree farmers and sites for research and extension activities. In: ACIAR Smallholder Forestry Project - Improving Financial Returns to Smallholder Tree Farmers in the Philippines: Project Planning Workshop, Ormoc City, 15-17 February. (J. Suh, S. Harrison, J. Herbohn, E. Mangaoang and J. Vanclay, eds). The University of Queensland, Brisbane, Australia, pp. 110-20.

CEDAMON, E., EMTAGE, N., SUH, J., HERBOHN, J., HARRISON, S. and E. MANGAOANG. 2005. Present tree planting and management activities in four rural communities in Leyte Province, the Philippines. Annals of Tropical Research. 27(1): 19-34.

CEDAMON, E., MANGAOANG, E., HARRISON, S. and J. HERBOHN. 2007. Evaluation of reliability of village-based inventory of smallholder tree farms on Leyte Island, the Philippines. In: Improving the Triple Bottom Line Returns from Small-scale Forestry, (S. Harrison, A. Bosch and J. Herbohn, eds). Proceedings of an international conference held in Ormoc, the Philippines, 18-21 June 2007. The University of Queensland, Brisbane. pp. 79-88.

CEDAMON, J., CEDAMON, E., GREGORIO, N., HARRISON, S., MANGAOANG, E. and J. HERBOHN. 2007. Survey of timber entrepreneurs in Region 8 and Cebu, the Philippines: Preliminary findings. In: Proceedings of the IUFRO 3.08 International Conference. (S. Harrison, A. Bosch and J. Herbohn, eds). The University of Queensland, Brisbane.

DENR (DEPARTMENT OF ENVIRONMENT AND NATURAL RESOURCES). 2006. Timber and timber products flow study in the Philippines. Accessed 16 May 2007. $<$ http://forestry.denr.gov.ph/ttf.htm>.

DENR (DEPARTMENT OF ENVIRONMENT AND NATURAL RESOURCES). 2007. 2005 Philippine Forestry Statistics, Forest Management Bureau, DENR. Accessed 26 October 2007. <http://forestry.denr.gov.ph/stat2005.htm>.

DENR (DEPARTMENT OF ENVIRONMENT AND NATURAL RESOURCES). 2005. Memorandum Circular 2005-005: Adopting Forestry Definitions Concerning Forest Cover/Land Use. Quezon City.

EMTAGE, N.F. 2004. An Investigation of the Social and Economic Factors Affecting the Development of Small-scale Forestry in Leyte Province, the Philippines. PhD thesis, School of Natural and Rural Systems Management, The University of Queensland, Brisbane.

FAO (FOOD AND AGRICULTURAL OFFICE OF THE UNITED NATIONS) 2005. Global Forest Resources Assessment 2005 Country Report Philippines. FAO, Rome.

FAO (FOOD AND AGRICULTURAL OFFICE OF THE UNITED NATIONS) 2006. Global Forest Resources Assessment: Main Report, FAO Forestry Paper 147. FAO, Rome. 
GERMANO, E. 2000. Personal Communication, Senior Research Specialist, Department of Environment and Natural Resources Region 8, Tacloban City.

GREGORY, G. 1987. Resource Economics for Foresters. Wiley, New York.

HARRISON, S., EMTAGE, N. and E. NASAYAO. 2004. Past and present forestry support programs in the Philippines and lessons for the future. Small-scale Forest Economics, Management and Policy. 3(3): 301-17.

HERBOHN, J. 2005. ACIAR ASEM 2003/052 Project Document. Australian Centre for International Agricultural Research.

KLEMPERER, D. 2003. Forest Resource Economics and Finance. W. David Klemperer, Blacksburg.

MCTAGGART, D., FINDLAY, C. AND M. PARKIN. 2003. Economics, 4th edn. Pearson Education Australia Pty Ltd, French Forest, NSW.

PEARSE, P. 1990. Introduction to Forestry Economics. University of British Columbia, Vancouver.

SHIVER, B. and B. BORDERS. 1996. Sampling Techniques for Forest Resource Inventory. Wiley, New York.

VANCLAY, J., BAYNES, J. and E. CEDAMON. 2005. Site index equation for smallholder plantations of Gmelina arborea in Leyte Province, the Philippines. Small-scale Forestry. 7(1): 87-93.

WANG, S. and G. VAN KOOTEN. 2001. Forestry and the New Institutional Economics: An Application of Contract Theory to Forest Silvicultural Investment. Ashgate, Aldershot. 